\title{
Role of endothelial cell junctions in transendothelial cancer cell migration. A review
}

\author{
*Rabiu F. I. \\ *Department of Anatomy, \\ Faculty of Basic Medical Sciences, \\ College of Health Sciences, \\ Bayero University, Kano, Nigeria
}

*Department of Cellular and Molecular Physiology, University of Liverpool, UK

Email: rifage.ana@buk.edu.ng

\begin{abstract}
During metastasis, tumour cells must become migratory and travel towards a capillary within the tumour. They then degrade the matrix surrounding the pericytes and endothelial cells, insert themselves between endothelial cells, transverse the capillary wall, to then enter the blood stream. This process depends on the motile behaviour of the tumour cells as well as the role of endothelial cell-cell junctions, both including adherens junctions and tight junctions. Circulating tumour cells must next, adhere to the walls of the capillary at the site of secondary tumour formation. Here, they again traverse the capillary wall to enter tissues distant from the primary tumour. This review aim to discuss the basic architecture of the endothelial junctional complex as well as the role played by these components towards the transendothelial migration of cancer cells from the primary site to the secondary site. Proper understanding of the role played by each of these components could invariably lead to the development of novel adjuvant cancer chemotherapy.
\end{abstract}

Key words: Endothelial cells, Tight junctions, Gap junctions, Adherens junction, Metastasis.

\section{INTRODUCTION}

Endothelium refers to the monolayer single sheet of endothelial cells lining the inner aspect of the vascular lumen acting to separate the underlying tissues from the circulating blood (Chistiakov, Revin, et al., 2015; Curry \& Adamson, 2010), thereby forming a form of barrier for the passage of both macromolecules as well as blood cells from the circulation into the underlying tissues (Dejana et al., 1995; Dejana \& Vestweber, 2013). These barriers are made up by the endothelial cells through the interactions of various junctional structures, which acts to tightly regulate the endothelial barrier (Razakandrainibe et al., 2013). Two major types of intercellular junctions found to be associated with the ECs are the tight and adherens junctions (Bazzoni \& Dejana, 2004; Hirase \& Node, 2012). Dysfunctions or distortion of endothelial cellcell junctions by the tumours cells results in opening of these junctions leading to 
transendothelial migration of the tumour cells at a far distant sites. which now becomes the secondary site. This review focus on describing the role played by each of these intercellular junctional complexes components during the process of transendothelial migration of the cancer cells.

\section{An overview of general architecture of vascular system}

The vascular system, also known as the cardiovascular system is a system that is concerned with the distribution/circulation of blood as well as nutrients to and from the cells of the body. The vascular system is generally made up of the blood and lymphatics. The vascular wall is made up of three distinct layers known also as tunics. Inside out are the tunicaintima, tunica media and tunica adventitia.

The tunica intima has an endothelial cell layer lining the luminal cavity of the vessel and just beneath the Endothelial cells (EC) is the basal lamina onto which the EC lies. Next to the basal lamina is the sub-endothelial layer which is made up of elastic fibres hence referred to as the internal elastic membrane. Tunica media which is the middle vascular layer is made up of vascular smooth muscle cells as well as some interspersed elastic fibres i.e. depending on the type and size of vessel. Next to the smooth muscle layer is the external elastic membrane demarcating the tunica media from the tunica adventitia. The tunica adventitia is the most external coat and by and large, it is composed of connective tissue. (Figure 1).

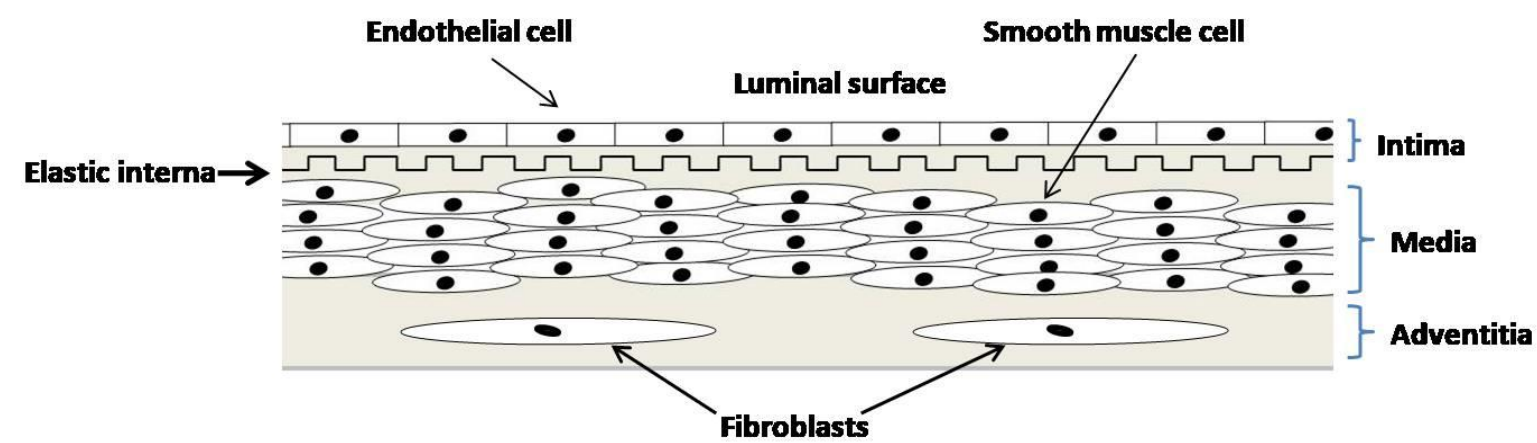

Figure 1. A cartoon diagram illustrating the three basic parts of a blood vessels. From the luminal aspect is the tunica intima followed by tunica media lying in between the tunica media and tunica adventitia. The outermost layer is the tunica adventitia.

\section{Endothelial cell architecture}

The vascular endothelium is made up of a single thin sheet layer of endothelial cells, which are flattened, elongated and polygonal in shape (simple squamous). The EC lines the entire inner aspect of the vascular system as earlier stated, as such forming a continuous inner layer. This layer of the endothelium in man has a surface area of $350 \mathrm{~m}^{2}$ and a total mass of $110 \mathrm{~g}$ (Pries \& Kuebler, 2006; Pries et al., 2000). The endothelium via the EC is actively involved in several important functions including, maintenance of selective permeability barrier, haemostasis and coagulation, inflammatory responses, fluid and solute exchange among others (Pries \& Kuebler, 2006; Pries et al., 2000). All the EC lie on the basal lamina. The EC along with tumour cells and most other cell types possess three forms of cytoskeletal components which are always in constant and close interaction with one another, through which they establish as well as regulate the endothelial barrier functions. These EC cytoskeletons are the actin microfilaments, intermediate filaments and microtubules (Chang \& Goldman, 2004; Dudek \& Garcia, 2001; Revenu et al., 2004).

The actin microfilaments on average are about $7 \mathrm{~nm}$ in diameter with intermediate filaments measuring about $10 \mathrm{~nm}$ and microtubules being about $25 \mathrm{~nm}$ in diameter (Ishikawa et al., 1968). Inside the EC actin constitutes about $5-15 \%$ of the total proteins (Patterson \& Lum, 
2001). Actin cytoskeleton exhibits a dynamic nature of polymerization and depolymerization. Polymerization of $\beta$-actin and $\gamma$-actin globular $(G)$ subunits results in the formation of filamentous (F) actin. The G-actin and F-actin are found to be in an equal amount within the cell (Stossel et al., 1985). However, the F actin is the main structural unit for the formation of actin-based cytoskeletal structures. The F actin cytoskeleton is composed of three distinct subtypes, comprising of cortical actin rim, outer membrane skeleton, with cross-linking of spectrin and the cytosolic actomyosin-based stress fibres (Prasain \& Stevens, 2009). The Factin filaments of the cortical actin are longer than the filaments of the membrane skeleton and stress fibres (De Matteis \& Morrow, 2000; Heimann et al., 1999). In cultured endothelial cells, the actin stress fibres generate centripetal tension in addition to the reorganization of adhesion complex architecture, which eventually results to retraction of cell-cell borders into apparent gaps (Dudek \& Garcia, 2001; Phillips et al., 1989). The cortical actin rim subsequently generates an outwards centrifugal tension to counteract the tension generated by stress fibres so as to prevent the collapse of the cultured motile cells. The cytosolic actomyosin-based stress fibres are necessary for cell contraction (Hotulainen \& Lappalainen, 2006) during which they determine the rate and size of the inter-endothelial cell gaps (Dudek \& Garcia, 2001; Patterson \& Lum, 2001). Therefore, the endothelial contractile machinery consists of actin and nonmuscle myosin, which requires ATP, calcium and calmodulin in order to generate contractile force for centripetal tension (Dudek \& Garcia, 2001; Surapisitchat \& Beavo, 2011). The endothelial cell contraction is generated sequel to process of phosphorylation of myosin light chain (MLC) by MLC-kinase (MLCK), which occur either as mono-phosphorylation on Ser19 or di-phosphorylation on both Ser19 and Thr18 (Goeckeler \& Wysolmerski, 1995; Prasain \& Stevens, 2009). MLCK, a calcium / calmodulin- dependent enzyme (Mehta \& Malik, 2006), in the human endothelial cell is a protein with a molecular weight of $214 \mathrm{kDa}$, and present on chromosome 3 (Dudek \& Garcia, 2001). Attenuation of MLC kinase activity results in distortion of endothelial barrier function (Garcia et al., 1995). Wainwright and colleagues reported increased protection in lung vascular permeability following the injection of lipopolysaccharide in endothelial cell MLCK -/- mice (Wainwright et al., 2003).

The intermediate-sized filaments have an average diameter of about 10nm (Ishikawa et al., 1968). The intermediate filaments of the EC are constituted by the polymers of cytokeratin and also vimentin(Patton et al., 1990). The filaments possess the ability to extend their length from both of the ends (Mehta \& Malik, 2006). The intermediate filaments in epithelial cells play an important role in cell-cell junctions and cell-ECM junctions at the desmosomes and hemidesmosomes through the interactions of transmembrane desmoglein and desmocollin proteins. Desmoglein and desmocollin are members belonging to the cadherin family (Garrod \& Chidgey, 2008; Mechanic et al., 1991). Unlike epithelial cells, ECs do not possess desmosomes (Lampugnani \& Dejana, 1997; Rubin, 1992) rather, the EC vimentin is usually linked to the adheren junction structure which is similar to the desmosomes, thereby forming an adherens complex (complexus adherens) (Kowalczyk et al., 1998; Schmelz \& Franke, 1993; Schmelz et al., 1994; Valiron et al., 1996). In addition, vimentin through desmoplakin, an intermediate filament-binding protein is able to form a link between the adheren junction and intermediate filaments of the EC (Shasby et al., 2002). Also, an alternative link between AJ and intermediate filaments could be established through the desmoplakin binding to the AJ armadillo protein p0071 (Calkins et al., 2003; Valiron et al., 1996). During inflammation, mediators are capable of disrupting the normal interaction between intermediate filament, $\mathrm{Y}^{-}$ catenin as well as the VE-cadherin (Shasby et al., 2002). However, vimentin knock-out mice lacking endothelial cell intermediate filaments did not exhibit any structural abnormality in their EC (Colucci-Guyon et al., 1994). 
Microtubules are rigid hollow polymer tubes of tubulin formed through the organisation and assembly of the $a$ and $\beta$ tubulins heterodimers, which originates from the microtubuleorganizing center (MTOC) close to the cell nucleus to then spread up to the periphery of the cell (Prasain \& Stevens, 2009; Wade \& Hyman, 1997). Each of the tubulins is about 55 $\mathrm{kDa}$ (Chretien \& Wade, 1991). As the microtubules extend throughout the cytosol it utilizes the motor proteins dynein and kinesin thereby providing a good platform which allows intracellular transport of proteins throughout the cell (Krylyshkina et al., 2002; Lambert et al., 1997; Wade \& Hyman, 1997). Microtubule has an outer diameter of $25 \mathrm{~nm}$ while its inner diameter is $12 \mathrm{~nm}$ (Wade \& Hyman, 1997). The $\alpha$ and $\beta$ tubulins subunits polymerize in a head-to-tail fashion thereby forming protofilaments which is subsequently aligned lengthwise along the microtubule. The protofilaments formed associate laterally to form a single microtubule having a hollow space measuring $12 \mathrm{~nm}$ in diameter at the inner aspect (Kikkawa et al., 1994). The wall of a single microtubule, therefore, is made from approximately 13-14 parallel protofilaments (Chretien et al., 1992; Kikkawa et al., 1994). Thus these rigid hollow rods assists EC in resisting compression through opposing actin-myosin contractility (Mehta \& Malik, 2006). The microtubule, unlike the intermediate filaments, displays a distinct polarity at their ends. These are the plus (+) and minus (-) ends. The plus end have the $\beta$ tubulins subunit exposed. It is the faster-growing end, found to be attached to the cortical actin layer on the inner face of the plasma membrane, and elongation is faster at this end compared to the minus end which has a tubulin subunit exposed (Grego et al., 2001; WatermanStorer \& Salmon, 1997). The exposed $\beta$ tubulin at the plus end binds to and hydrolyses GTP to GDP, thereby allowing dynamic treadmilling of the microtubule, while the exposed a tubulin does not hydrolyse its attached GTP (Grego et al., 2001; WatermanStorer \& Salmon, 1997). It is important to note that though microtubules do not extend to the plasma membrane (ConacciSorrell et al., 2002; Dejana, 2004; Dudek \& Garcia, 2001; Lampugnani et al., 2002) and also do not directly interact with cellular junctions (Vincent et al., 2004), they are capable of delivering cell junction components to the cell surface through the vesicular trafficking of p120 catenin, a component of $\mathrm{AJ}$ as well as the delivery of connexin hemi-channels for the gap junction channels (Chen et al., 2003; Lauf et al., 2002; Shaw et al., 2007; Yanagisawa et al., 2004). Microtubules are always in a dynamic state of assembly and disassembly and initially, microtubules and actin filaments were regarded as individual entities. However several studies have revealed an intricate association between microtubule and actin (Fuchs \& Yang, 1999; Goode et al., 2000; Klymkowsky, 1999; Prasain \& Stevens, 2009). The interaction between microtubule and actin could be direct via the microtubule-associated proteins or indirectly via the intermediate linker or scaffolding proteins (Goode et al., 2000; Lee \& Gotlieb, 2002; Lee \& Gotlieb, 2003), including coronin (Goode et al., 1999), centractin (Clark \& Meyer, 1992) and IQGAP1 (Brunner, 2002; Fukata et al., 2002) which bind to both microtubules and actin. The mechanism of IQGAP1 is well understood. The IQGAP1 cross-links via its amino terminus with $\mathrm{F}$ actin and then provides a carboxyl terminus as the binding site for microtubule-binding proteins CLIP-170 and EB1 (Brunner, 2002; Fukata et al., 2002; Watanabe et al., 2004). Both CLIP-170 and EB1 are microtubule plus end protein (Gundersen, 2002; Schuyler \& Pellman, 2001). Also, EB1 has dual binding sites at its C-terminus for $\mathrm{p} 150$, is a component of the dynein / kinesin complex (Askham et al., 2002; Berrueta et al., 1999). In addition $\beta$-catenin, which is a component of AJs, could also bind to dynein thereby indirectly linking the $\mathrm{AJ}$ to the plus end of microtubule and therefore is suggested to link the microtubule plus-end to AJs (Chausovsky et al., 2000; Komarova et al., 2000; Ligon et al., 2001). Furthermore, disruption of microtubule like the disruption of the cortical actin network has been reported to impair the endothelial cell barrier function. Microtubule disruption activates Rho guanine exchange factors (RhoGEFs), from tubulin, resulting in Rho A activation and subsequent stress fiber formation (Krendel et al., 2002; van Horck et al., 2001), while polymerisation of microtubule sequesters LIM kinase 1 thereby, restricting its access to the actin cytoskeleton and preventing 
the formation of stress fibres (Gorovoy et al., 2005; Maekawa et al., 1999). Interestingly chemotherapeutic agents such as vinca alkaloids were reported to cause pulmonary oedema secondary to microtubule disruption (Cattan \& Oberg, 1999). Also, inhibition of the motor protein activity of kinesin-1 or treatment using a depolymerising agent such as nocodazole has been shown to cause increased endothelial permeability (Verin et al., 2001). Thus, microtubule proves to be critical for the maintenance of cell shape as well as barrier integrity of the endothelium.

\section{Endothelial cell-cell contacts and junctions}

The ECs along the vascular tree maintain contact with each other through intercellular junctions. The barrier function of the ECs is known to be highly mediated by these junctions, in addition to keeping the ECs together. The architecture of the junctions along the vascular system is highly heterogeneous and depends on specific requirements of a particular organ (Engelhardt \& Wolburg, 2004; Wolburg \& Lippoldt, 2002). The intercellular junctions are highly dynamic and as such play an important role in the maintenance of vascular homeostasis as well as in inflammation during the transendothelial migration of leukocytes. Disruption of these junctions in disease conditions including cancers often leads to the breakdown of the EC barrier, increasing the permeability (Engelhardt \& Wolburg, 2004; Goswami \& Vestweber, 2016). At least three main types of intercellular junctions have been described in endothelial cells: Tight junctions (TJ), Adherens junctions (AJ) and Gap junctions (GJ) as illustrated in the Figure 2. These junctions are briefly described below.

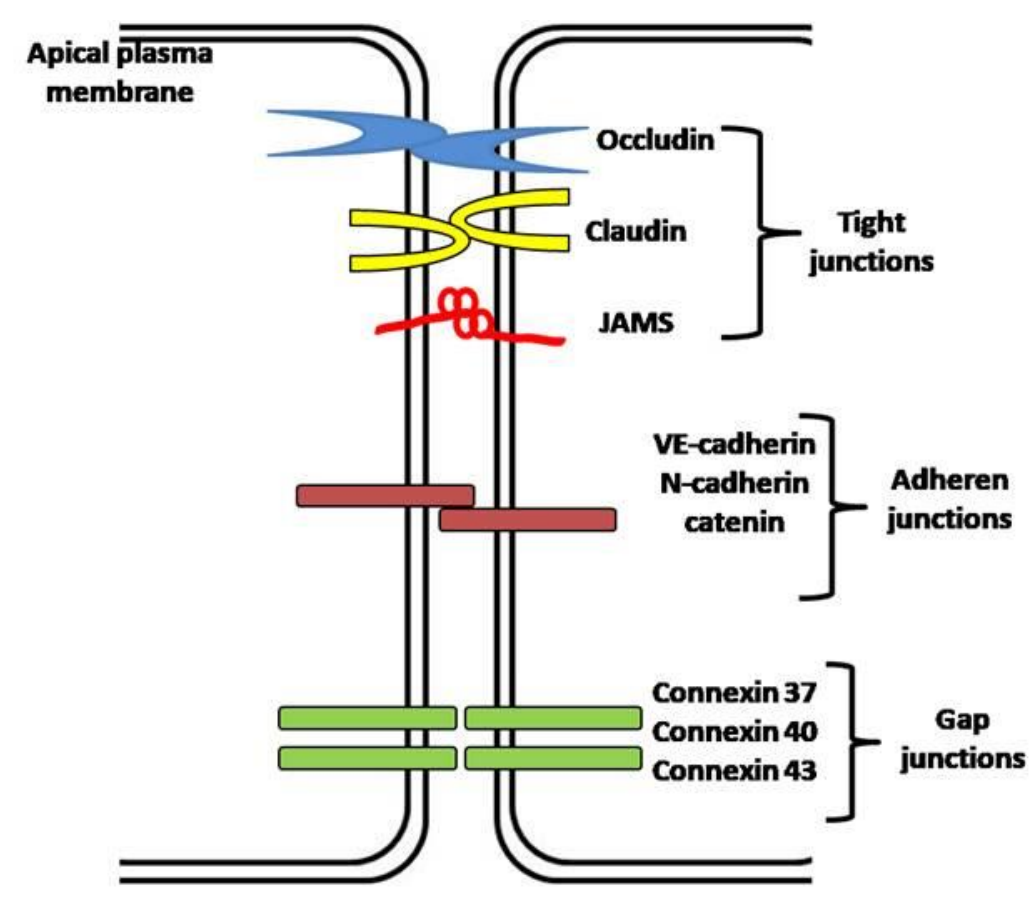

Figure 2. Endothelial cells junctions. The figure illustrates the main types of junctions present in vascular endothelial cells, tight junctions, adherens junctions and gap junctions. Tight junctions are usually the most apical in epithelial cells and less restricted in endothelial cells. TJ components include occludin (blue), claudin (yellow) and junctional adhesion molecules (JAMs) (red). Adherens junctions in endothelial cells are formed mainly by VEcadherin. Also, N-cadherin is found to be expressed by ECs. Gap junctions in endothelial cells are formed from connexin proteins, mainly connexins 37,40 and 43 . These junctions are paracellular channels responsible for the intercellular exchange of ions as well as small molecules.

\section{Tight junctions}


Tight junctions (TJ) are found to be present in both epithelial and endothelial cells. TJ was identified as a specialization of the plasma membrane via electron microscopy in 1963 (Farquhar \& Palade, 1963). Freeze fracture study shows the TJ to be composed of a network of linear fibrils intersected by short transversal fibrils (Anderson et al., 1993; Gumbiner, 1993). The TJ in ECs, unlike those in epithelial cells, is less structured and more intermixed with the adherens junctions. They are found to be the most apical amongst all the junctional complexes in both epithelial and endothelial cells (Bazzoni \& Dejana, 2004; Chistiakov, Orekhov, et al., 2015). They provide both barrier or gate function through regulation of entry and exit of ions, water, and macromolecules between cells (paracellulary), as well as fence function thereby establishing and maintaining the polarity of the cell (Bazzoni \& Dejana, 2004; Chistiakov, Orekhov, et al., 2015; Dejana, 2004; Tsukita et al., 2001). The distribution of TJ varies along the vascular network and depends largely on the requirement for endothelial permeability (Simionescu \& Simionescu, 1991). The endothelium of large arteries tends to have a welldeveloped tight junction system while TJs are absent in post capillary venules (Aird, 2007; Simionescu \& Simionescu, 1991; Wallez \& Huber, 2008). Additionally, TJs are found to be well developed in brain and retina where they form the blood-brain barrier and blood-retinal barrier, respectively (Simionescu et al., 1975; Wallez \& Huber, 2008). Finally, recently the loss of TJ barrier function have been described to play a role in cancer metastasis (Martin, 2014; Martin \& Jiang, 2009). In ECs as well as epithelial cells the TJs are formed by the homophilic interaction of cell-cell adhesion molecules, which are membrane-associated proteins. These include claudins, occludins, and junction adhesion molecules (JAMs) (Balda \& Matter, 2016; Ebnet, 2008; Radeva \& Waschke, 2018).

Claudins, a family of proteins are the major barrier-forming proteins in TJs (Tsukita \& Furuse, 1999; Tsukita et al., 2019). They comprise of more than 20 members, with a low molecular mass of 20-27 kDa. Claudin members are capable of establishing both homophilic binding and heterophilic binding (Furuse \& Tsukita, 2006; Runkle \& Mu, 2013; Tsukita \& Furuse, 1999). Claudin, like occludin, possesses four membrane-spanning regions, thus referred to as a tetraspan protein, with two extracellular loops and two cytoplasmic termini ( $\mathrm{N}$ - and Ctermini) (Bazzoni \& Dejana, 2004; Chiba et al., 2008; Van Itallie \& Anderson, 2014). The cytoplasmic C-terminus of claudin bears a PDZ motif through which it recruits PDZ scaffolding proteins (Hamazaki et al., 2002; Itoh et al., 1999; Roh et al., 2002). ECs in humans have been reported to express claudin-1, $-3,-5,-12$, and -15 (Chistiakov, Orekhov, et al., 2015; Kiuchi-Saishin et al., 2002; Morita et al., 1999; Witt et al., 2003). Recent studies have reported an increase in TJ permeability following knockdown of claudin-1 in human ECs (Asaka et al., 2011). Additionally, Claudin-5-knockout mice often have developed severe brain haemorrhage due to selective impairment in BBB function for molecules smaller than $800 \mathrm{Da}$ (Nitta et al., 2003; Runkle \& Mu, 2013). Taken together the above evidence points to the key role of claudin- 1 and claudin- 5 in the regulation of endothelial TJ permeability.

Occludin was the first transmembrane protein to be discovered in tight junctions (Furuse et al., 1993). It has a molecular mass of $65-\mathrm{kDa}$. It is also a tetraspan protein, with two extracellular loops and two cytoplasmic termini (N- and C-termini) (Furuse et al., 1993). Occludin through its $\mathrm{C}$ - terminus binds several proteins within the cytoplasm including zona occludens ( $\mathrm{ZO})$, in this manner mediating the interaction between the adhesion molecules and actin filaments (Balda \& Matter, 2016; Balda et al., 1996). Additionally, ZO also binds to the adherens junction proteins afadin and a-catenin (Itoh et al., 1997; Ooshio et al., 2010; Rajasekaran et al., 1996). Although claudins are essential for TJ formation, in contrast, occludin is not essential, but rather serves as a major component for the formation of $\mathrm{TJ}$ complexes in the presence of claudins (Furuse et al., 1998). Occludin plays an important role in maintaining the stability and barrier function of the tight junctions (Furuse et al., 1993; Schneeberger \& 
Lynch, 2004). Occludin is known to be entirely localized to the tight Junctions of both epithelial and endothelial cells and its expression in the endothelium largely correlates with the permeability function along the vascular network (Anderson et al., 1993; Chiba et al., 2008). Additionally, occludin is found to be highly expressed brain endothelial as well as in retinal endothelial cells where they form BBB and BRB respectively (Hirase et al., 1997). Downregulation of occludin has been reported to be associated with disease conditions affecting BBB and BRB (Brown \& Davis, 2002). The TJ of ECs in occludin-null mice were intact and devoid of any gross alterations (Saitou et al., 2000), however these mice demonstrated several abnormal phenotypes including postnatal growth retardation, thinning of compact bone, calcification in the brain, testicular atrophy, male infertility, loss of cytoplasmic granules in salivary epithelial cells, females not suckling their young, and gastric inflammation and hyperplasia (Saitou et al., 2000). These suggest the complexity associated with occludin functions and also its role in stabilisation of the tight junctions.

Junctional adhesion molecules (JAMs), unlike the previous two proteins already described, are a family of single membrane-spanning proteins with an extracellular domain of two IgGlike folds, a transmembrane domain, and a cytoplasmic tail (Martin-Padura et al., 1998). The JAMs are subdivided into two subgroups, with JAM-A, JAM-B and JAM-C belonging to the first subgroup (Ebnet et al., 2003; Ebnet et al., 2001; Itoh et al., 2001) and coxsackie and adenovirus receptor (CAR), endothelial cell-selective adhesion molecule (ESAM) and JAM4 as the members of the second group (Kansaku et al., 2006; Sollerbrant et al., 2003). The first subgroup has a class II PDZ domain-binding motif at their C-terminal ends, through which directly interacts with ZO-1 and PAR-3 (Ebnet et al., 2003; Ebnet et al., 2001; Itoh et al., 2001), whereas the second subgroup bears class I PDZ domain-binding motif at their C-terminus (Bazzoni, 2003; Chiba et al., 2008; Ebnet et al., 2004; Kansaku et al., 2006). JAMs are capable of establishing both homophilic and heterophilic adhesion through their extracellular domains (Bazzoni, 2003; Ebnet et al., 2004). In addition to being present in TJ of EC cells, JAMs are also found in other cells including leucocytes where they play an important role in their transendothelial migration (Ebnet et al., 2004). JAM-A is to be found in intercellular junctions between epithelial and endothelial cells, as well as on the membranes of platelets and leukocytes (Martin-Padura et al., 1998; Williams et al., 1999), JAM-B expression is, however, restricted to inter-endothelial junctions, mainly in post capillary endothelial cells and lymphatic vessels (Palmeri et al., 2000). Though JAM-C is expressed in endothelial cells, its tissue distribution, by and large, varies between mouse and human (Morris et al., 2006). In JAM-A -/- mice, antibody treatment using anti-JAM-A antibody was shown to have no effect on the transendothelial migration of neutrophils (Corada et al., 2005; Khandoga et al., 2005). Recently Seung-Eon and colleagues reported a reduction in the transendothelial migration of bone marrow-derived dendritic cells following treatment with a junctional adhesion molecule (JAM)-Like (JAML) antibody (anti-JAML) (Roh et al., 2018). The above evidence demonstrates the important role played by JAMs in TEM, thus taken together JAMs could serve as a therapeutic target for metastasis control in neuroblastoma patients.

\section{Gap junctions}

Gap junctions (GJs) are composed of clusters of intercellular channels largely formed through the hexameric assemblies of connexins, which are located between adjacent cells (Goodenough et al., 1996). Two hexameric connexins from adjacent cells interact with each other through the narrow extracellular gap of about $\sim 2 \mathrm{~nm}$, from which the junction derives its name (Yeager \& Nicholson, 1996). The GJs in addition to providing direct cell-cell communications also allows the exchange of ions as well as small signalling molecules $(\sim<1$ kDa) between adjacent cells (Carter \& Ogden, 1994; Evans et al., 2006; Hsiao et al., 2010; Laird, 2006). In chordates, the connexins are made up of 21 family members (Alexopoulos et al., 2004; 
Cruciani \& Mikalsen, 2007). Amongst the 21 known connexins, Cx37, Cx40, and Cx43 are the main connexins identified to be expressed by the endothelial cells within the human vascular network (Evans \& Martin, 2002; vanRijen et al., 1997; Yeh et al., 1998). In the beginning, the channel function of gap junctions was mainly ascribed to the functional activity described as gap junction intercellular communication (GJIC) (Kotini \& Mayor, 2015; Simon \& Goodenough, 1998). Apart from their channel function, gap junctions additionally play a role in cell-cell adhesion through an association with the tight junctions (Evans \& Martin, 2002; Severs et al., 2001). This function is largely carried out by the cysteine residues of the extracellular loops. Previous studies reported an increase in the adhesive ability of glioma cells due to an exogenous expression of connexin (Lin et al., 2002). Similarly, a reduction in cell-cell adhesion was observed following a point mutation in a cysteine residue of the extracellular loop (Lin et al., 2002). Additionally, in cancers, high expression of Cx26 was detected on the plasma membranes of mouse skin cancer cells invading the lymph node (Kamibayashi et al., 1995), and a similar finding was reported in the prostate as well as in breast cancer (Kanczuga-Koda et al., 2006). Recently, in the light of a possible role in cancer metastasis, Zhang and colleagues showed that inhibition of the highly expressed Cx43 in multiple myeloma cells using 18 a-glycyrrhetinic acid, a blocker for Cx43, markedly decreased adhesion and migratory capabilities of multiple myeloma cells (Zhang et al., 2015). Another study demonstrated an up-regulation of $\mathrm{Cx} 43$ in the region of contact between the tumour cell and endothelial cell (Elzarrad et al., 2008). Finally, pieces of evidence are beginning to emerge for the role of $\mathrm{Cx} 43$ in facilitating cancer cell intravasation and extravasation as revealed by the experiment using 4T-1 mouse breast cancer cell lines that eventually metastasises to the brain. In this study, up-regulation of connexin- 43 was shown to be associated at the regions of tumour cell-endothelial cell contact both in vitro and in vivo, as well as in regions of intra-tumour blood vessels and micro-metastatic foci (Elzarrad et al., 2008; Stoletov et al., 2013). By and large, the preceding evidence points to the roles of gap junctions in adhesion as well as in metastasis suggesting that gap junction could serve as a therapeutic means for metastasis.

\section{Adherens junctions (AJs)}

AJs are found to be widely distributed along the vascular network. These junctions are made up of transmembrane spanning proteins which are found to be expressed by the endothelial cells of both blood and lymphatic vessels (Bazzoni \& Dejana, 2004; Dejana et al., 1995). The transmembrane spanning adhesion proteins in AJs are known to be of the cadherin family (Aberle et al., 1996; Angst et al., 2001a, 2001b; Gumbiner, 2000; Yagi \& Takeichi, 2000). Of the $>20$ members of the cadherin superfamily, the endothelial cells specifically express vascular endothelial (VE)-cadherin (Dejana et al., 1995). Additionally, during embryonic development, (VE)-cadherin was also found to be expressed in cytotrophoblastic cells as well as in the cells committed to the endothelial lineage (Breier et al., 1996; Fraser et al., 2003; Kim et al., 2005).

Cadherins were primarily identified within AJs through immunoelectron microscopic study in 1984 (Volk \& Geiger, 1984). These cell-cell adhesion molecules are of 120-140 kDa molecular mass (Geiger \& Ayalon, 1992) and they mediate their function in a $\mathrm{Ca}^{2+}$ dependent manner (Volk \& Geiger, 1984, 1986). Cadherins, a single transmembrane glycoprotein, act through the formation of homotypic adhesive complexes with neighbouring EC(Steinberg \& McNutt, 1999). Structurally, classical cadherins are characterized by the presence of a long extracellular domain, a transmembrane domain and a short cytoplasmic domain (Figure 3). The extracellular region consists of the N-terminus and 5 extracellular repeats, EC1-EC5 (Lampugnani et al., 1992; Liaw et al., 1990). These 5 extracellular repeats (EC) are further subdivided into two groups; EC1-3 are inter-homologous ectodomains, each approximately 110 amino acids long, while EC4 and EC5 are less homologous repeats (Takeichi, 1990). The 
extracellular domains are highly important in determining the specificity of the cadherin interactions (Ivanov et al., 2001; Lampugnani et al., 1992; Liaw et al., 1990). Each EC repeat expresses two putative calcium-binding sites (Ozawa et al., 1990; Ringwald et al., 1987), and modification in form of a single amino acid substitution at the calcium-binding site is adequate to eliminate the adhesive function of the molecule (Ozawa et al., 1990). The cytoplasmic domain of cadherins interacts with the cytoplasmic proteins including catenins, which, function as an intermediate linker between the cadherins and actin filaments (Ozawa et al., 1990; Rimm et al., 1995; Takeichi, 1995). Functionally, the cytoplasmic domain comprises of the juxtamembrane domain, which is responsible for cadherin-p120 catenin and cadherinp0071 interactions, and the $\mathrm{COOH}$-terminal domain which interacts with either $\beta$-catenin or $\gamma$-catenin in a discordant manner (Bazzoni \& Dejana, 2004; Zhurinsky et al., 2000). As mentioned earlier, vascular endothelial (VE)-cadherin (also known as cadherin-5 and CD144) is the main cadherin expressed in endothelial adherens junctions (Lampugnani et al., 1992) and is structurally similar to the classical cadherin as described above. Thus the (VE)-cadherin acts to modulate the permeability of the endothelial barrier via the activity of AJ complex (Barry et al., 2015; Corada et al., 2001; Corada et al., 1999; Mehta \& Malik, 2006). In as much as the AJ modulates the EC barrier a range of molecules and even cells, ions and solutes may perhaps move across ECs via either a paracellular or transcellular manner (Mehta et al., 2014). Increase in permeability of EC barrier is encountered during inflammation and also in vascular pathologies including oedema, tumour angiogenesis as well as sepsis which often results from the disruption of integrity of the VE-cadherin adhesion complex (AragonSanabria et al., 2017; Corada et al., 2001; Crosby et al., 2005; Frye et al., 2015). During inflammation, leukocytes were found to largely pass between the ECs while transmigrating across the endothelial layer (Tsukita et al., 2001; Vestweber, 2012; Vestweber et al., 2014). Several studies have characterised the various events leading to the breakdown endothelial barrier (Allport et al., 2000; Muller, 2014; Shaw et al., 2001; Tinsley et al., 1999; Vestweber, $2008,2015)$. Evelyn and colleagues observed the loss of VE-cadherin from the retracting endothelial junction at the contact region between the ECs and melanoma cells, which led to a further redistribution of VE-cadherin (Voura et al., 1998). Furthermore, recently Virginia and colleagues observed activation of SRC, a non-receptor tyrosine kinase, to mediate the disassembly of VE-cadherin in ECs during the process of TEM of metastatic melanoma cells (Aragon-Sanabria et al., 2017).

Taken together, these results suggest that ECs VE-cadherin plays an important role during the TEM events in cancers and thus adequate understanding of signalling events modulating the VE-cadherin at the endothelial junctions might identify novel therapeutic targets towards treatment of cancer metastasis.

(VE)-cadherin also interacts with nectins, a cell-cell adhesion molecule, thereby forming a junctional complex, through which they likely mediate the formation of a mature AJ (Noda et al., 2010; Wallez \& Huber, 2008). The nectin cell adhesion molecules are an immunoglobulin family with four members (nectins 1-4), together with five of the nectin like molecules (Necl 1-5) (Takai et al., 2003). Two of the nectin members, nectin 2 and nectin 3 are found to be expressed in endothelial cells (Lopez et al., 2001; Takai et al., 2003). Like cadherins, nectin interaction leads to the formation of cis and trans dimers across the cell junctions (Takahashi et al., 1999). The nectins interact either homophilically and heterophilically via a calciumindependent manner to establish proper cell-cell adhesion (Dong et al., 2006; Takai et al., 2003). The C-terminus of nectins, bears the postsynaptic density protein-95/ discs large/ ZO-1 (PDZ) binding motif, through which it binds to an actin-binding filament afadin which gets anchored to the actin cytoskeleton of the AJ as well as the TJ (Takahashi et al., 1999; Takai et 
al., 2003). Thus nectin-afadin interaction is crucial for the establishment of strong adherens junctions (Sato et al., 2006).

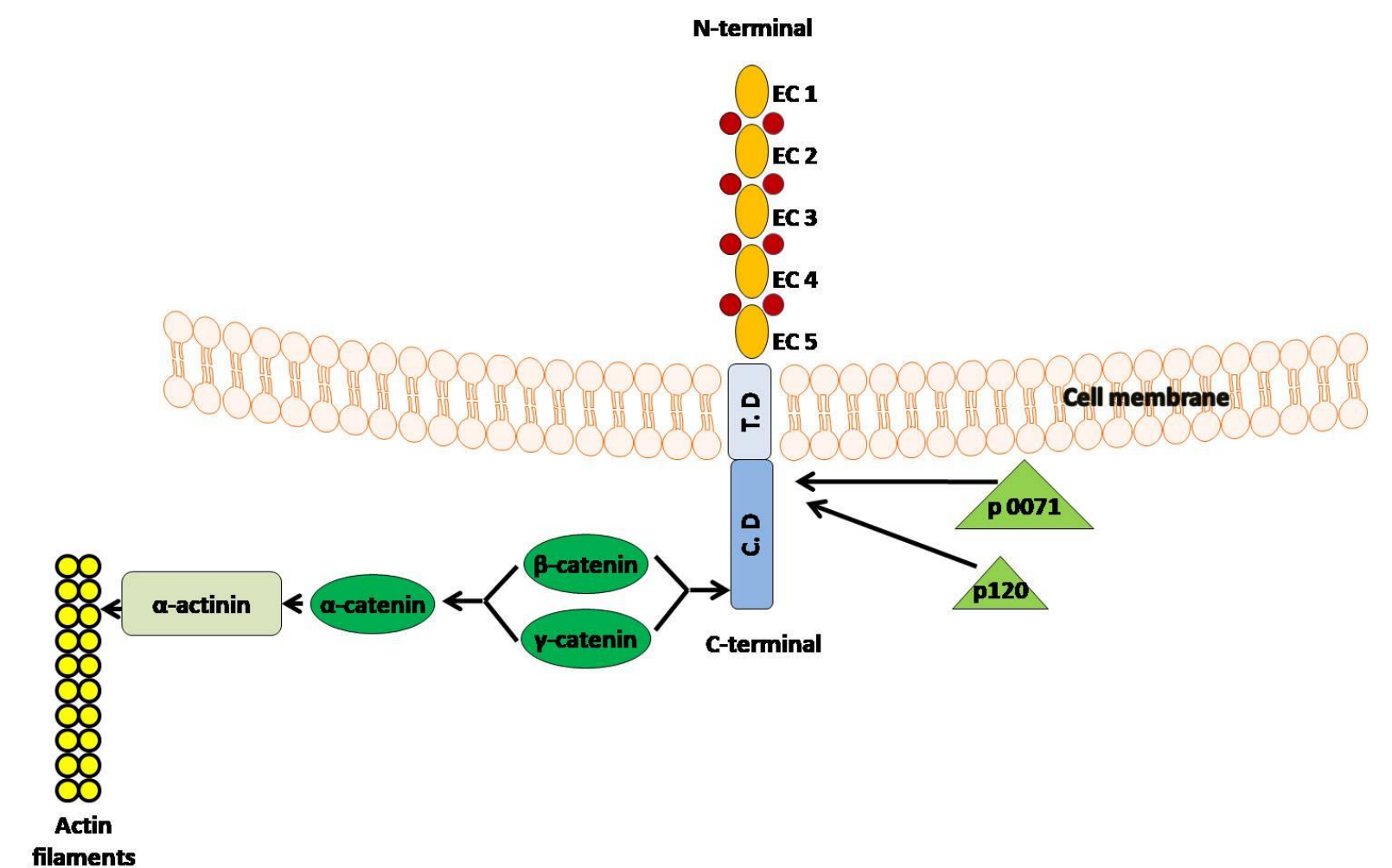

Figure 3. Structure of classical cadherin. The cartoon illustrates the structure of a classical cadherin depicting all the three domains. 5 extracellular domains (EC1-5) (pink) form the extracellular region, with the N-terminus. The EC region expresses two calcium-binding sites. The transmembrane domain (T.D) (light blue).The cytoplasmic domain (C.D, blue) which comprises of two parts thus juxtamembrane domain which serves a region for the binding of armadillo proteins p120 and p0071 bind (light green), and a COOH-terminal domain where either $\beta$ catenin or $\gamma$-catenin bind (green). $\alpha$-actinin (green) can bind to either $\beta$-catenin or $\gamma$-catenin, which can then bind to a-actinin (gray). Finally, a-actinin can bind to the actin cytoskeleton (yellow) to establish the cadherin / catenin complex.

\section{CONCLUSION}

It is highly important to note that cancer metastasis is a highly complex event involving both cancer cells and the endothelial junctional complexes. Adequate and proper knowledge of the interactions as well as the role individual role played by these junctions could serve as a target point for the treatment of metastasis which often times is the cause of high mortality. Recently pharmacological agents in form of small molecules which modulates the integrity and function of endothelial junctions are being developed. Further exploration of the role of these junctions will eventually have a great impact towards the management of metastasis in numerous cancers.

\section{REFERENCES}

Aberle, H., Schwartz, H., \& Kemler, R. (1996). Cadherin-catenin complex: Protein interactions and their implications for cadherin function. Journal of Cellular Biochemistry, 61(4), 514-523. https://doi.org/10.1002/(sici)10974644(19960616)61:4<514::aid-jcb4>3.3.co;2-d

Aird, W. C. (2007). Phenotypic heterogeneity of the endothelium I. Structure, function, and mechanisms. Circulation Research, 100(2), 158-173. https://doi.org/10.1161/01.RES.0000255691.76142.4a 
Alexopoulos, H., Bottger, A., Fischer, S., Levin, A., Wolf, A., Fujisawa, T., . . Bacon, J. P. (2004). Evolution of gap junctions: The missing link? Current Biology, 14(20), R879R880. https://doi.org/10.1016/j.cub.2004.09.067

Allport, J. R., Muller, W. A., \& Luscinskas, F. W. (2000). Monocytes induce reversible focal changes in vascular endothelial cadherin complex during transendothelial migration under flow. Journal of Cell Biology, 148(1), 203-216. https:/ / doi.org/10.1083/jcb.148.1.203

Anderson, J. M., Balda, M. S., \& Fanning, A. S. (1993). The structure and regulation of tight junctions. Current Opinion in Cell Biology, 5(5), 772-778. https://doi.org/10.1016/0955-0674(93)90024-k

Angst, B. D., Marcozzi, C., \& Magee, A. I. (2001a). The cadherin superfamily. Journal of Cell Science, 114(4), 625-626.

Angst, B. D., Marcozzi, C., \& Magee, A. I. (2001b). The cadherin superfamily: diversity in form and function. Journal of Cell Science, 114(4), 629-641.

Aragon-Sanabria, V., Pohler, S. E., Eswar, V. J., Bierowski, M., Gomez, E. W., \& Dong, C. (2017). VE-Cadherin Disassembly and Cell Contractility in the Endothelium are Necessary for Barrier Disruption Induced by Tumor Cells. Scientific Reports, 7, Article 45835. https://doi.org/10.1038/srep45835

Asaka, M., Hirase, T., Hashimoto-Komatsu, A., \& Node, K. (2011). Rab5a-mediated localization of claudin-1 is regulated by proteasomes in endothelial cells. American Journal of Physiology-Cell Physiology, 300(1), C87-C96. https:/ / doi.org/10.1152/ajpcell.00565.2010

Askham, J. M., Vaughan, K. T., Goodson, H. V., \& Morrison, E. E. (2002). Evidence that an interaction between EB1 and p150(Glued) is required for the formation and maintenance of a radial microtubule array anchored at the centrosome. Mol Biol Cell, 13(10), 3627-3645. https:// doi.org/10.1091/mbc.e02-01-0061

Balda, M. S., \& Matter, K. (2016). Tight junctions as regulators of tissue remodelling. Current Opinion in Cell Biology, 42, 94-101. https://doi.org/10.1016/j.ceb.2016.05.006

Balda, M. S., Whitney, J. A., Flores, C., Gonzalez, S., Cereijido, M., \& Matter, K. (1996). Functional dissociation of paracellular permeability and transepithelial electrical resistance and disruption of the apical-basolateral intramembrane diffusion barrier by expression of a mutant tight junction membrane protein. Journal of Cell Biology, 134(4), 1031-1049. https:/ / doi.org/10.1083/jcb.134.4.1031

Barry, A. K., Wang, N., \& Leckband, D. E. (2015). Local VE-cadherin mechanotransduction triggers long-ranged remodeling of endothelial monolayers. Journal of Cell Science, 128(7), 1341-1351. https:/ / doi.org/10.1242/jcs.159954

Bazzoni, G. (2003). The JAM family of junctional adhesion molecules. Current Opinion in Cell Biology, 15(5), 525-530. https:/ / doi.org/10.1016/s0955-0674(03)00104-2

Bazzoni, G., \& Dejana, E. (2004). Endothelial cell-to-cell junctions: Molecular organization and role in vascular homeostasis. Physiological Reviews, 84(3), 869-901. https://doi.org/10.1152/physrev.00035.2003

Berrueta, L., Tirnauer, J. S., Schuyler, S. C., Pellman, D., \& Bierer, B. E. (1999). The APCassociated protein EB1 associates with components of the dynactin complex and cytoplasmic dynein intermediate chain. Curr Biol, 9(8), 425-428.

Breier, G., Breviario, F., Caveda, L., Berthier, R., Schnurch, H., Gotsch, U., . . . Dejana, E. (1996). Molecular cloning and expression of murine vascular endothelial cadherin in early stage development of cardiovascular system. Blood, 87(2), 630-641.

Brown, R. C., \& Davis, T. P. (2002). Calcium modulation of adherens and tight junction function - A potential mechanism for blood-brain barrier disruption after stroke. Stroke, 33(6), 1706-1711. https:// doi.org/10.1161/01.str.0000016405.06729.83 
Brunner, D. (2002). How to grab a microtubule on the move. Developmental Cell, 3(1), 2-4. https:/ / doi.org/10.1016/s1534-5807(02)00209-5

Calkins, C. C., Hoepner, B. L., Law, C. M., Novak, M. R., Setzer, S. V., Hatzfeld, M., \& Kowalczyk, A. P. (2003). The Armadillo family protein p0071 is a VE-cadherin- and desmoplakin-binding protein. J Biol Chem, 278(3), 1774-1783. https://doi.org/10.1074/jbc.M205693200

Carter, T. D., \& Ogden, D. (1994). ACETYLCHOLINE-STIMULATED CHANGES OF MEMBRANE-POTENTIAL AND INTRACELLULAR CA2+ CONCENTRATION RECORDED IN ENDOTHELIAL-CELLS IN-SITU IN THE ISOLATED RAT AORTA. Pflugers Archiv-European Journal of Physiology, 428(5-6), 476-484. https:/ / doi.org/10.1007/bf00374568

Cattan, C. E., \& Oberg, K. C. (1999). Vinorelbine tartrate-induced pulmonary edema confirmed on rechallenge. Pharmacotherapy, 19(8), 992-994. https:/ / doi.org/10.1592/phco.19.11.992.31580

Chang, L., \& Goldman, R. D. (2004). Intermediate filaments mediate cytoskeletal crosstalk. Nature Reviews Molecular Cell Biology, 5(8), 601-613. https:/ / doi.org/10.1038/nrm1438

Chausovsky, A., Bershadsky, A. D., \& Borisy, G. G. (2000). Cadherin-mediated regulation of microtubule dynamics. Nature Cell Biology, 2(11), 797-804.

Chen, X. Y., Kojima, S., Borisy, G. G., \& Green, K. J. (2003). p120 catenin associates with kinesin and facilitates the transport of cadherin-catenin complexes to intercellular junctions. Journal of Cell Biology, 163(3), 547-557. https:/ / doi.org/10.1083/jcb.200305137

Chiba, H., Osanai, M., Murata, M., Kojima, T., \& Sawada, N. (2008). Transmembrane proteins of tight junctions. Biochimica Et Biophysica Acta-Biomembranes, 1778(3), 588600. https://doi.org/10.1016/j.bbamem.2007.08.017

Chistiakov, D. A., Orekhov, A. N., \& Bobryshev, Y. V. (2015). Endothelial Barrier and Its Abnormalities in Cardiovascular Disease. Frontiers in Physiology, 6, Article 365. https:/ / doi.org/10.3389/fphys.2015.00365

Chistiakov, D. A., Revin, V. V., Sobenin, I. A., Orekhov, A. N., \& Bobryshev, Y. V. (2015). Vascular Endothelium: Functioning in Norm, Changes in Atherosclerosis and Current Dietary Approaches to Improve Endothelial Function. Mini-Reviews in Medicinal Chemistry, 15(4), 338-350. https:/ / doi.org/10.2174/1389557515666150226114031

Chretien, D., Metoz, F., Verde, F., Karsenti, E., \& Wade, R. H. (1992). LATTICE-DEFECTS IN MICROTUBULES - PROTOFILAMENT NUMBERS VARY WITHIN INDIVIDUAL MICROTUBULES. Journal of Cell Biology, 117(5), 1031-1040. https:/ / doi.org/10.1083/jcb.117.5.1031

Chretien, D., \& Wade, R. H. (1991). NEW DATA ON THE MICROTUBULE SURFACE LATTICE. Biology of the Cell, 71(1-2), 161-174. https:/ / doi.org/10.1016/02484900(91)90062-r

Clark, S. W., \& Meyer, D. I. (1992). CENTRACTIN IS AN ACTIN HOMOLOG ASSOCIATED WITH THE CENTROSOME. Nature, 359(6392), 246-250. https://doi.org/10.1038/359246a0

Colucci-Guyon, E., Portier, M. M., Dunia, I., Paulin, D., Pournin, S., \& Babinet, C. (1994). Mice lacking vimentin develop and reproduce without an obvious phenotype. Cell, 79(4), 679-694.

Conacci-Sorrell, M., Zhurinsky, J., \& Ben-Ze'ev, A. (2002). The cadherin-catenin adhesion system in signaling and cancer. Journal of Clinical Investigation, 109(8), 987-991. https:/ / doi.org/10.1172/jci200215429 
Corada, M., Chimenti, S., Cera, M. R., Vinci, M., Salio, M., Fiordaliso, F., .. . Dejana, E. (2005). Junctional adhesion molecule-A-deficient polyrnorphonuclear cells show reduced diapedesis in peritonitis and heart ischemia-reperfusion injury. Proceedings of the National Academy of Sciences of the United States of America, 102(30), 10634-10639. https:/ / doi.org/10.1073/pnas.0500147102

Corada, M., Liao, F., Lindgren, M., Lampugnani, M. G., Breviario, F., Frank, R., . . Dejana, E. (2001). Monoclonal antibodies directed to different regions of vascular endothelial cadherin extracellular domain affect adhesion and clustering of the protein and modulate endothelial permeability. Blood, 97(6), 1679-1684. https://doi.org/10.1182/blood.V97.6.1679

Corada, M., Mariotti, M., Thurston, G., Smith, K., Kunkel, R., Brockhaus, M., . . Dejana, E. (1999). Vascular endothelial-cadherin is an important determinant of microvascular integrity in vivo. Proceedings of the National Academy of Sciences of the United States of America, 96(17), 9815-9820. https://doi.org/10.1073/pnas.96.17.9815

Crosby, C. V., Fleming, P. A., Argraves, W. S., Corada, M., Zanetta, L., Dejana, E., \& Drake, C. J. (2005). VE-cadherin is not required for the formation of nascent blood vessels but acts to prevent their disassembly. Blood, 105(7), 2771-2776. https:/ / doi.org/10.1182/blood-2004-06-2244

Cruciani, V., \& Mikalsen, S. O. (2007). Evolutionary selection pressure and family relationships among connexin genes. Biological Chemistry, 388(3), 253-264. https://doi.org/10.1515/bc.2007.028

Curry, F. R. E., \& Adamson, R. H. (2010). Vascular permeability modulation at the cell, microvessel, or whole organ level: towards closing gaps in our knowledge. Cardiovascular Research, 87(2), 218-229. https://doi.org/10.1093/cvr/cvq115

De Matteis, M. A., \& Morrow, J. S. (2000). Spectrin tethers and mesh in the biosynthetic pathway. Journal of Cell Science, 113(13), 2331-2343.

Dejana, E. (2004). Endothelial cell-cell junctions: Happy together. Nature Reviews Molecular Cell Biology, 5(4), 261-270. https:// doi.org/10.1038/nrm1357

Dejana, E., Corada, M., \& Lampugnani, M. G. (1995). ENDOTHELIAL CELL-TO-CELL JUNCTIONS. Faseb Journal, 9(10), 910-918.

Dejana, E., \& Vestweber, D. (2013). The Role VE-Cadherin in Vascular Morphogenesis and Permeability Control. Molecular Biology of Cadherins, 116, 119-144. https:/ / doi.org/10.1016/b978-0-12-394311-8.00006-6

Dong, X. H., Xu, F., Gong, Y. H., Gao, J., Lin, P., Chen, T., . . Rao, Z. H. (2006). Crystal structure of the $\mathrm{v}$ domain of human nectin-like molecule-1/Syncam3/Tsll1/Igsf4b, a neural tissue-specific immunoglobulin-like cell-cell adhesion molecule. Journal of Biological Chemistry, 281(15), 10610-10617. https:/ / doi.org/10.1074/jbc.M513459200

Dudek, S. M., \& Garcia, J. G. (2001). Cytoskeletal regulation of pulmonary vascular permeability. J Appl Physiol (1985), 91(4), 1487-1500. https:/ / doi.org/10.1152/jappl.2001.91.4.1487

Ebnet, K. (2008). Organization of multiprotein complexes at cell-cell junctions. Histochemistry and Cell Biology, 130(1), 1-20. https://doi.org/10.1007/s00418-008-0418-7

Ebnet, K., Aurrand-Lions, M., Kuhn, A., Kiefer, F., Butz, S., Zander, K., . . . Vestweber, D. (2003). The junctional adhesion molecule (JAM) family members JAM-2 and JAM-3 associate with the cell polarity protein PAR-3: a possible role for JAMs in endothelial cell polarity. Journal of Cell Science, 116(19), 3879-3891. https:/ / doi.org/10.1242/jcs.00704

Ebnet, K., Suzuki, A., Horikoshi, Y., Hirose, T., Meyer zu Brickwedde, M. K., Ohno, S., \& Vestweber, D. (2001). The cell polarity protein ASIP/PAR-3 directly associates with junctional adhesion molecule (JAM). Embo Journal, 20(14), 3738-3748. https:/ / doi.org/10.1093/emboj/20.14.3738 
Ebnet, K., Suzuki, A., Ohno, S., \& Vestweber, D. (2004). Junctional adhesion molecules (JAMs): more molecules with dual functions? Journal of Cell Science, 117(1), 19-29. https:/ / doi.org/10.1242/jcs.00930

Elzarrad, M. K., Haroon, A., Willecke, K., Dobrowolski, R., Gillespie, M. N., \& Al-Mehdi, A. B. (2008). Connexin-43 upregulation in micrometastases and tumor vasculature and its role in tumor cell attachment to pulmonary endothelium. Bmc Medicine, 6, Article 20. https:// doi.org/10.1186/1741-7015-6-20

Engelhardt, B., \& Wolburg, H. (2004). Mini-review: Transendothelial migration of leukocytes: through the front door or around the side of the house? European Journal of Immunology, 34(11), 2955-2963. https:/ / doi.org/10.1002/eji.200425327

Evans, W. H., De Vuyst, E., \& Leybaert, L. (2006). The gap junction cellular internet: connexin hemichannels enter the signalling limelight. Biochemical Journal, 397, 1-14. https:// doi.org/10.1042/bj20060175

Evans, W. H., \& Martin, P. E. M. (2002). Gap junctions: structure and function (Review). Molecular Membrane Biology, 19(2), 121-136. https:/ / doi.org/10.1080/09687680210139839

Farquhar, M. G., \& Palade, G. E. (1963). JUNCTIONAL COMPLEXES IN VARIOUS EPITHELIA. Journal of Cell Biology, 17(2), 375-\&. https:// doi.org/10.1083/jcb.17.2.375

Fraser, S. T., Yamashita, J., Jakt, L. M., Okada, M., Ogawa, M., Nishikawa, S., \& Nishikawa, S. I. (2003). In vitro differentiation of mouse embryonic stem cells: Hematopoietic and vascular cell types. Differentiation of Embryonic Stem Cells, 365, 59-72.

Frye, M., Dierkes, M., Kuppers, V., Vockel, M., Tomm, J., Zeuschner, D., . . Vestweber, D. (2015). Interfering with VE-PTP stabilizes endothelial junctions in vivo via Tie-2 in the absence of VE-cadherin. Journal of Experimental Medicine, 212(13), 2267-2287. https:/ / doi.org/10.1084/jem.20150718

Fuchs, E., \& Yang, Y. (1999). Crossroads on cytoskeletal highways. Cell, 98(5), 547-550.

Fukata, M., Watanabe, T., Noritake, J., Nakagawa, M., Yamaga, M., Kuroda, S., . . Kaibuchi, K. (2002). Rac1 and Cdc42 capture microtubules through IQGAP1 and CLIP-170. Cell, 109(7), 873-885. https:// doi.org/10.1016/s0092-8674(02)00800-0

Furuse, M., Hirase, T., Itoh, M., Nagafuchi, A., Yonemura, S., \& Tsukita, S. (1993). OCCLUDIN - A NOVEL INTEGRAL MEMBRANE-PROTEIN LOCALIZING AT TIGHT JUNCTIONS. Journal of Cell Biology, 123(6), 1777-1788. https:/ / doi.org/10.1083/jcb.123.6.1777

Furuse, M., Sasaki, H., Fujimoto, K., \& Tsukita, S. (1998). A single gene product, claudin-1 or -2 , reconstitutes tight junction strands and recruits occludin in fibroblasts. Journal of Cell Biology, 143(2), 391-401. https:// doi.org/10.1083/jcb.143.2.391

Furuse, M., \& Tsukita, S. (2006). Claudins in occluding junctions of humans and flies. Trends in Cell Biology, 16(4), 181-188. https:// doi.org/10.1016/j.tcb.2006.02.006

Garcia, J. G., Pavalko, F. M., \& Patterson, C. E. (1995). Vascular endothelial cell activation and permeability responses to thrombin. Blood Coagul Fibrinolysis, 6(7), 609-626.

Garrod, D., \& Chidgey, M. (2008). Desmosome structure, composition and function. Biochimica Et Biophysica Acta-Biomembranes, 1778(3), 572-587. https:/ / doi.org/10.1016/j.bbamem.2007.07.014

Geiger, B., \& Ayalon, O. (1992). CADHERINS. Annual Review of Cell Biology, 8, 307-332. https:/ / doi.org/10.1146/annurev.cb.08.110192.001515

Goeckeler, Z. M., \& Wysolmerski, R. B. (1995). MYOSIN LIGHT-CHAIN KINASEREGULATED ENDOTHELIAL-CELL CONTRACTION - THE RELATIONSHIP BETWEEN ISOMETRIC TENSION, ACTIN POLYMERIZATION, AND MYOSIN PHOSPHORYLATION. Journal of Cell Biology, 130(3), 613-627. https:/ / doi.org/10.1083/jcb.130.3.613 
Goode, B. L., Drubin, D. G., \& Barnes, G. (2000). Functional cooperation between the microtubule and actin cytoskeletons. Current Opinion in Cell Biology, 12(1), 63-71. https:/ / doi.org/10.1016/s0955-0674(99)00058-7

Goode, B. L., Wong, J. J., Butty, A. C., Peter, M., McCormack, A. L., Yates, J. R., . . Barnes, G. (1999). Coronin promotes the rapid assembly and cross-linking of actin filaments and may link the actin and microtubule cytoskeletons in yeast. Journal of Cell Biology, 144(1), 83-98. https:// doi.org/10.1083/jcb.144.1.83

Goodenough, D. A., Goliger, J. A., \& Paul, D. L. (1996). Connexins, connexons, and intercellular communication. Annual Review of Biochemistry, 65, 475-502. https:/ / doi.org/10.1146/annurev.bi.65.070196.002355

Gorovoy, M., Niu, J. X., Bernard, O., Profirovic, J., Minshall, R., Neamu, R., \& VoynoYasenetskaya, T. (2005). LIM kinase 1 coordinates microtubule stability and actin polymerization in human endothelial cells. Journal of Biological Chemistry, 280(28), 26533-26542. https:// doi.org/10.1074/jbc.M502921200

Goswami, D., \& Vestweber, D. (2016). How leukocytes trigger opening and sealing of gaps in the endothelial barrier. F1000Res, 5. https:/ / doi.org/10.12688/f1000research.9185.1

Grego, S., Cantillana, V., \& Salmon, E. D. (2001). Microtubule treadmilling in vitro investigated by fluorescence speckle and confocal microscopy. Biophysical Journal, 81(1), 66-78. https:// doi.org/10.1016/s0006-3495(01)75680-9

Gumbiner, B. M. (1993). BREAKING THROUGH THE TIGHT JUNCTION BARRIER. Journal of Cell Biology, 123(6), 1631-1633. https://doi.org/10.1083/jcb.123.6.1631

Gumbiner, B. M. (2000). Regulation of cadherin adhesive activity. Journal of Cell Biology, 148(3), 399-403. https:// doi.org/10.1083/jcb.148.3.399

Gundersen, G. G. (2002). Evolutionary conservation of microtubule-capture mechanisms. Nature Reviews Molecular Cell Biology, 3(4), 296-304. https:/ / doi.org/10.1038/nrm777

Hamazaki, Y., Itoh, M., Sasaki, H., Furuse, M., \& Tsukita, S. (2002). Multi-PDZ domain protein 1 (MUPP1) is concentrated at tight junctions through its possible interaction with claudin-1 and junctional adhesion molecule. Journal of Biological Chemistry, 277(1), 455-461. https://doi.org/10.1074/jbc.M109005200

Heimann, K., Percival, J. M., Weinberger, R., Gunning, P., \& Stow, J. L. (1999). Specific isoforms of actin-binding proteins on distinct populations of Golgi-derived vesicles. Journal of Biological Chemistry, 274(16), 10743-10750. https://doi.org/10.1074/jbc.274.16.10743

Hirase, T., \& Node, K. (2012). Endothelial dysfunction as a cellular mechanism for vascular failure. American Journal of Physiology-Heart and Circulatory Physiology, 302(3), H499H505. https:/ / doi.org/10.1152/ajpheart.00325.2011

Hirase, T., Staddon, J. M., Saitou, M., AndoAkatsuka, Y., Itoh, M., Furuse, M., . . Rubin, L. L. (1997). Occludin as a possible determinant of tight junction permeability in endothelial cells. Journal of Cell Science, 110, 1603-1613.

Hotulainen, P., \& Lappalainen, P. (2006). Stress fibers are generated by two distinct actin assembly mechanisms in motile cells. Journal of Cell Biology, 173(3), 383-394. https://doi.org/10.1083/jcb.200511093

Hsiao, H. J., Liu, P. A., Yeh, H. I., \& Wang, C. Y. (2010). Classical swine fever virus downregulates endothelial connexin 43 gap junctions. Archives of Virology, 155(7), 11071116. https:// doi.org/10.1007/s00705-010-0693-1

Ishikawa, H., Bischoff, R., \& Holtzer, H. (1968). MITOSIS AND INTERMEDIATE-SIZED FILAMENTS IN DEVELOPING SKELETAL MUSCLE. Journal of Cell Biology, 38(3), 538-\&. https://doi.org/10.1083/jcb.38.3.538

Itoh, M., Furuse, M., Morita, K., Kubota, K., Saitou, M., \& Tsukita, S. (1999). Direct binding of three tight junction-associated MAGUKs, ZO-1, ZO-2 and ZO-3, with the $\mathrm{COOH}$ 
termini of claudins. Journal of Cell Biology, 147(6), 1351-1363.

https:/ / doi.org/10.1083/jcb.147.6.1351

Itoh, M., Nagafuchi, A., Moroi, S., \& Tsukita, S. (1997). Involvement of ZO-1 in cadherinbased cell adhesion through its direct binding to or catenin and actin filaments. Journal of Cell Biology, 138(1), 181-192. https://doi.org/10.1083/jcb.138.1.181

Itoh, M., Sasaki, H., Furuse, M., Ozaki, H., Kita, T., \& Tsukita, S. (2001). Junctional adhesion molecule (JAM) binds to PAR-3: a possible mechanism for the recruitment of PAR-3 to tight junctions. Journal of Cell Biology, 154(3), 491-497. https:/ / doi.org/10.1083/jcb.200103047

Ivanov, D. B., Philippova, M. P., \& Tkachuk, V. A. (2001). Structure and functions of classical cadherins. Biochemistry-Moscow, 66(10), 1174-1186. https://doi.org/10.1023/a:1012445316415

Kamibayashi, Y., Oyamada, Y., Mori, M., \& Oyamada, M. (1995). ABERRANT EXPRESSION OF GAP JUNCTION PROTEINS (CONNEXINS) IS ASSOCIATED WITH TUMOR PROGRESSION DURING MULTISTAGE MOUSE SKIN CARCINOGENESIS INVIVO. Carcinogenesis, 16(6), 1287-1297. https:/ / doi.org/10.1093/carcin/16.6.1287

Kanczuga-Koda, L., Sulkowski, S., Lenczewski, A., Koda, M., Wincewicz, A., Baltaziak, M., \& Sulkowska, M. (2006). Increased expression of connexins 26 and 43 in lymph node metastases of breast cancer. Journal of Clinical Pathology, 59(4), 429-433. https:/ / doi.org/10.1136/jcp.2005.029272

Kansaku, A., Hirabayashi, S., Mori, H., Fujiwara, N., Kawata, A., Ikeda, M., . . . Hata, Y. (2006). Ligand-of-Numb protein $X$ is an endocytic scaffold for junctional adhesion molecule 4. Oncogene, 25(37), 5071-5084. https:/ / doi.org/10.1038/sj.onc.1209468

Khandoga, A., Kessler, J. S., Meissner, H., Hanschen, M., Corada, M., Motoike, T., . . . Krombach, F. (2005). Junctional adhesion molecule-A deficiency increases hepatic ischemia-reperfusion injury despite reduction of neutrophil transendothelial migration. Blood, 106(2), 725-733. https:// doi.org/10.1182/blood-2004-11-4416

Kikkawa, M., Ishikawa, T., Nakata, T., Wakabayashi, T., \& Hirokawa, N. (1994). DIRECT VISUALIZATION OF THE MICROTUBULE LATTICE SEAM BOTH IN-VITRO AND IN-VIVO. Journal of Cell Biology, 127(6), 1965-1971. https://doi.org/10.1083/jcb.127.6.1965

Kim, I., Yilmaz, O. H., \& Morrison, S. J. (2005). CD144 (VE-cadherin) is transiently expressed by fetal liver hematopoietic stem cells. Blood, 106(3), 903-905. https:/ / doi.org/10.1182/blood-2004-12-4960

Kiuchi-Saishin, Y., Gotoh, S., Furuse, M., Takasuga, A., Tano, Y., \& Tsukita, S. (2002). Differential expression patterns of claudins, tight junction membrane proteins, in mouse nephron segments. Journal of the American Society of Nephrology, 13(4), Article Unsp 1046-6673/1304-0875.

Klymkowsky, M. W. (1999). Weaving a tangled web: the interconnected cytoskeleton. Nature Cell Biology, 1(5), E121-E123. https:// doi.org/10.1038/12950

Komarova, Y. A., Maly, I., Vorobjev, I. A., \& Borisy, G. G. (2000). Cadherin-mediated regulation of microtubule plus-end dynamics. Molecular Biology of the Cell, 11, 359A359A.

Kotini, M., \& Mayor, R. (2015). Connexins in migration during development and cancer. Developmental Biology, 401(1), 143-151. https://doi.org/10.1016/j.ydbio.2014.12.023

Kowalczyk, A. P., Navarro, P., Dejana, E., Bornslaeger, E. A., Green, K. J., Kopp, D. S., \& Borgwardt, J. E. (1998). VE-cadherin and desmoplakin are assembled into dermal microvascular endothelial intercellular junctions: a pivotal role for plakoglobin in the recruitment of desmoplakin to intercellular junctions. J Cell Sci, 111 ( Pt 20), 30453057. 
Krendel, M., Zenke, F. T., \& Bokoch, G. M. (2002). Nucleotide exchange factor GEF-H1 mediates cross-talk between microtubules and the actin cytoskeleton. Nature Cell Biology, 4(4), 294-301. https:// doi.org/10.1038/ncb773

Krylyshkina, O., Kaverina, I., Kranewitter, W., Steffen, W., Alonso, M. C., Cross, R. A., \& Small, J. V. (2002). Modulation of substrate adhesion dynamics via microtubule targeting requires kinesin-1. Journal of Cell Biology, 156(2), 349-359. https://doi.org/10.1083/jcb.200105051

Laird, D. W. (2006). Life cycle of connexins in health and disease. Biochemical Journal, 394, 527-543. https://doi.org/10.1042/ bj20051922

Lambert, S., Davis, J. Q., \& Bennett, V. (1997). Morphogenesis of the node of Ranvier: Coclusters of ankyrin and ankyrin-binding integral proteins define early developmental intermediates. Journal of Neuroscience, 17(18), 7025-7036.

Lampugnani, M. G., \& Dejana, E. (1997). Interendothelial junctions: structure, signalling and functional roles. Curr Opin Cell Biol, 9(5), 674-682.

Lampugnani, M. G., Resnati, M., Raiteri, M., Pigott, R., Pisacane, A., Houen, G., . . Dejana, E. (1992). A NOVEL ENDOTHELIAL-SPECIFIC MEMBRANE-PROTEIN IS A MARKER OF CELL CELL CONTACTS. Journal of Cell Biology, 118(6), 1511-1522. https://doi.org/10.1083/jcb.118.6.1511

Lampugnani, M. G., Zanetti, A., Breviario, F., Balconi, G., Orsenigo, F., Corada, M., . . . Dejana, E. (2002). VE-cadherin regulates endothelial actin activating Rac and increasing membrane association of Tiam. Molecular Biology of the Cell, 13(4), 11751189. https://doi.org/10.1091/mbc.01-07-0368

Lauf, U., Giepmans, B. N. G., Lopez, P., Braconnot, S., Chen, S. C., \& Falk, M. M. (2002). Dynamic trafficking and delivery of connexons to the plasma membrane and accretion to gap junctions in living cells. Proceedings of the National Academy of Sciences of the United States of America, 99(16), 10446-10451.

https://doi.org/10.1073/pnas.162055899

Lee, J. S. Y., \& Gotlieb, A. I. (2002). Microtubule-actin interactions may regulate endothelial integrity and repair. Cardiovascular Pathology, 11(3), 135-140, Article Pii s10548807(01)00080-1. https:// doi.org/10.1016/s1054-8807(01)00080-1

Lee, T. Y. J., \& Gotlieb, A. I. (2003). Microfilaments and Microtubules maintain endothelial integrity. Microscopy Research and Technique, 60(1), 115-125. https:/ / doi.org/10.1002/jemt.10250

Liaw, C. W., Cannon, C., Power, M. D., Kiboneka, P. K., \& Rubin, L. L. (1990). Identification and cloning of two species of cadherins in bovine endothelial cells. Embo j, 9(9), 27012708.

Ligon, L. A., Karki, S., Tokito, M., \& Holzbaur, E. L. F. (2001). Dynein binds to beta-catenin and may tether microtubules at adherens junctions. Nature Cell Biology, 3(10), 913917. https://doi.org/10.1038/ncb1001-913

Lin, J. H. C., Takano, T., Cotrina, M. L., Arcuino, G., Kang, J., Liu, S. J., . . N Nedergaard, M. (2002). Connexin 43 enhances the adhesivity and mediates the invasion of malignant glioma cells. Journal of Neuroscience, 22(11), 4302-4311. https:/ / doi.org/10.1523/jneurosci.22-11-04302.2002

Lopez, I., Mak, E. C., Ding, J., Hamm, H. E., \& Lomasney, J. W. (2001). A novel bifunctional phospholipase $c$ that is regulated by Galpha 12 and stimulates the Ras/mitogenactivated protein kinase pathway. J Biol Chem, 276(4), 2758-2765. https://doi.org/10.1074/jbc.M008119200

Maekawa, M., Ishizaki, T., Boku, S., Watanabe, N., Fujita, A., Iwamatsu, A., . . Narumiya, S. (1999). Signaling from Rho to the actin cytoskeleton through protein kinases ROCK and LIM-kinase. Science, 285(5429), 895-898. 
Martin, T. A. (2014). The role of tight junctions in cancer metastasis. Seminars in Cell $\mathcal{E}$ Developmental Biology, 36, 224-231. https:// doi.org/10.1016/j.semcdb.2014.09.008

Martin, T. A., \& Jiang, W. G. (2009). Loss of tight junction barrier function and its role in cancer metastasis. Biochimica Et Biophysica Acta-Biomembranes, 1788(4), 872-891. https:/ / doi.org/10.1016/j.bbamem.2008.11.005

Martin-Padura, I., Lostaglio, S., Schneemann, M., Williams, L., Romano, M., Fruscella, P., . . . Dejana, E. (1998). Junctional adhesion molecule, a novel member of the immunoglobulin superfamily that distributes at intercellular junctions and modulates monocyte transmigration. Journal of Cell Biology, 142(1), 117-127. https://doi.org/10.1083/jcb.142.1.117

Mechanic, S., Raynor, K., Hill, J. E., \& Cowin, P. (1991). DESMOCOLLINS FORM A DISTINCT SUBSET OF THE CADHERIN FAMILY OF CELL-ADHESION MOLECULES. Proceedings of the National Academy of Sciences of the United States of America, 88(10), 4476-4480. https://doi.org/10.1073/pnas.88.10.4476

Mehta, D., \& Malik, A. B. (2006). Signaling mechanisms regulating endothelial permeability. Physiological Reviews, 86(1), 279-367. https:// doi.org/10.1152/physrev.00012.2005

Mehta, D., Ravindran, K., \& Kuebler, W. M. (2014). Novel regulators of endothelial barrier function. American Journal of Physiology-Lung Cellular and Molecular Physiology, 307(12), L924-L935. https:/ / doi.org/10.1152/ajplung.00318.2014

Morita, K., Furuse, M., Fujimoto, K., \& Tsukita, S. (1999). Claudin multigene family encoding four-transmembrane domain protein components of tight junction strands.

Proceedings of the National Academy of Sciences of the United States of America, 96(2), 511516. https://doi.org/10.1073/pnas.96.2.511

Morris, A. P., Tawil, A., Berkova, Z., Wible, L., Smith, C. W., \& Cunningham, S. A. (2006). Junctional Adhesion Molecules (JAMs) are differentially expressed in fibroblasts and co-localize with ZO-1 to adherens-like junctions. Cell Communication and Adhesion, 13(4), 233-247. https:// doi.org/10.1080/15419060600877978

Muller, W. A. (2014). How Endothelial Cells Regulate Transmigration of Leukocytes in the Inflammatory Response. American Journal of Pathology, 184(4), 886-896. https:/ / doi.org/10.1016/j.ajpath.2013.12.033

Nitta, T., Hata, M., Gotoh, S., Seo, Y., Sasaki, H., Hashimoto, N., . . Tsukita, S. (2003). Sizeselective loosening of the blood-brain barrier in claudin-5-deficient mice. Journal of Cell Biology, 161(3), 653-660. https://doi.org/10.1083/jcb.200302070

Noda, K., Zhang, J., Fukuhara, S., Kunimoto, S., Yoshimura, M., \& Mochizuki, N. (2010). Vascular endothelial-cadherin stabilizes at cell-cell junctions by anchoring to circumferential actin bundles through alpha- and beta-catenins in cyclic AMP-EpacRap1 signal-activated endothelial cells. Mol Biol Cell, 21(4), 584-596.

https:/ / doi.org/10.1091/mbc.E09-07-0580

10.1091/mbc.e09-07-0580

Ooshio, T., Kobayashi, R., Ikeda, W., Miyata, M., Fukumoto, Y., Matsuzawa, N., . . Takai, Y. (2010). Involvement of the Interaction of Afadin with ZO-1 in the Formation of Tight Junctions in Madin-Darby Canine Kidney Cells. Journal of Biological Chemistry, 285(7), 5003-5012. https://doi.org/10.1074/jbc.M109.043760

Ozawa, M., Ringwald, M., \& Kemler, R. (1990). UVOMORULIN CATENIN COMPLEXFORMATION IS REGULATED BY A SPECIFIC DOMAIN IN THE CYTOPLASMIC REGION OF THE CELL-ADHESION MOLECULE. Proceedings of the National Academy of Sciences of the United States of America, 87(11), 4246-4250. https://doi.org/10.1073/pnas.87.11.4246

Palmeri, D., van Zante, A., Huang, C. C., Hemmerich, S., \& Rosen, S. D. (2000). Vascular endothelial junction-associated molecule, a novel member of the immunoglobulin 
superfamily, is localized to intercellular boundaries of endothelial cells. Journal of Biological Chemistry, 275(25), 19139-19145. https:/ / doi.org/10.1074/jbc.M003189200

Patterson, C. E., \& Lum, H. (2001). Update on pulmonary edema: the role and regulation of endothelial barrier function. Endothelium-Journal of Endothelial Cell Research, 8(2), 75-+. https:/ / doi.org/10.3109/10623320109165319

Patton, W. F., Yoon, M. U., Alexander, J. S., Chungwelch, N., Hechtman, H. B., \& Shepro, D. (1990). EXPRESSION OF SIMPLE EPITHELIAL CYTOKERATINS IN BOVINE PULMONARY MICROVASCULAR ENDOTHELIAL-CELLS. Journal of Cellular Physiology, 143(1), 140-149. https:/ / doi.org/10.1002/jcp.1041430119

Phillips, P. G., Lum, H., Malik, A. B., \& Tsan, M. F. (1989). PHALLACIDIN PREVENTS THROMBIN-INDUCED INCREASES IN ENDOTHELIAL PERMEABILITY TO ALBUMIN. American Journal of Physiology, 257(3), C562-C567.

Prasain, N., \& Stevens, T. (2009). The actin cytoskeleton in endothelial cell phenotypes. Microvascular Research, 77(1), 53-63. https:/ / doi.org/10.1016/j.mvr.2008.09.012

Pries, A. R., \& Kuebler, W. M. (2006). Normal endothelium. Handb Exp Pharmacol(176 Pt 1), 140.

Pries, A. R., Secomb, T. W., \& Gaehtgens, P. (2000). The endothelial surface layer. Pflugers Archiv-European Journal of Physiology, 440(5), 653-666. https:/ / doi.org/10.1007/s004240000307

Radeva, M. Y., \& Waschke, J. (2018). Mind the gap: mechanisms regulating the endothelial barrier. Acta Physiologica, 222(1), Article UNSP e12860. https:/ / doi.org/10.1111/apha.12860

Rajasekaran, A. K., Hojo, M., Huima, T., \& RodriguezBoulan, E. (1996). Catenins and zonula occludens- 1 form a complex during early stages in the assembly of tight junctions. Journal of Cell Biology, 132(3), 451-463. https:// doi.org/10.1083/jcb.132.3.451

Razakandrainibe, R., Combes, V., Grau, G. E., \& Jambou, R. (2013). Crossing the wall: the opening of endothelial cell junctions during infectious diseases. Int J Biochem Cell Biol, 45(7), 1165-1173. https:/ / doi.org/10.1016/j.biocel.2013.03.010

Revenu, C., Athman, R., Robine, S., \& Louvard, D. (2004). The co-workers of actin filaments: From cell structures to signals. Nature Reviews Molecular Cell Biology, 5(8), 635-646. https://doi.org/10.1038/nrm1437

Rimm, D. L., Koslov, E. R., Kebriaei, P., Cianci, C. D., \& Morrow, J. S. (1995). ALPHA(1)(E)CATENIN IS AN ACTIN-BINDING AND ACTIN-BUNDLING PROTEIN MEDIATING THE ATTACHMENT OF F-ACTIN TO THE MEMBRANE ADHESION COMPLEX. Proceedings of the National Academy of Sciences of the United States of America, 92(19), 8813-8817. https:/ / doi.org/10.1073/pnas.92.19.8813

Ringwald, M., Schuh, R., Vestweber, D., Eistetter, H., Lottspeich, F., Engel, J., . . et al. (1987). The structure of cell adhesion molecule uvomorulin. Insights into the molecular mechanism of Ca2+-dependent cell adhesion. Embo j, 6(12), 3647-3653.

Roh, M. H., Liu, C. J., Laurinec, S., \& Margolis, B. (2002). The carboxyl terminus of zona occludens-3 binds and recruits a mammalian homologue of discs lost to tight junctions. Journal of Biological Chemistry, 277(30), 27501-27509. https://doi.org/10.1074/jbc.M201177200

Roh, S. E., Jeong, Y., Kang, M. H., \& Bae, Y. S. (2018). Junctional adhesion molecules mediate transendothelial migration of dendritic cell vaccine in cancer immunotherapy. Cancer Letters, 434, 196-205. https:/ / doi.org/10.1016/j.canlet.2018.07.029

Rubin, L. L. (1992). Endothelial cells: adhesion and tight junctions. Curr Opin Cell Biol, 4(5), 830-833.

Runkle, E. A., \& Mu, D. (2013). Tight junction proteins: From barrier to tumorigenesis. Cancer Letters, 337(1), 41-48. https:/ / doi.org/10.1016/j.canlet.2013.05.038 
Saitou, M., Furuse, M., Sasaki, H., Schulzke, J. D., Fromm, M., Takano, H., . . Tsukita, S. (2000). Complex phenotype of mice lacking occludin, a component of tight junction strands. Molecular Biology of the Cell, 11(12), 4131-4142. https://doi.org/10.1091/mbc.11.12.4131

Sato, T., Fujita, N., Yamada, A., Ooshio, T., Okamoto, R., Irie, K., \& Takai, Y. (2006). Regulation of the assembly and adhesion activity of E-cadherin by nectin and afadin for the formation of adherens junctions in Madin-Darby canine kidney cells. Journal of Biological Chemistry, 281(8), 5288-5299. https://doi.org/10.1074/jbc.M510070200

Schmelz, M., \& Franke, W. W. (1993). Complexus adhaerentes, a new group of desmoplakincontaining junctions in endothelial cells: the syndesmos connecting retothelial cells of lymph nodes. Eur J Cell Biol, 61(2), 274-289.

Schmelz, M., Moll, R., Kuhn, C., \& Franke, W. W. (1994). Complexus adhaerentes, a new group of desmoplakin-containing junctions in endothelial cells: II. Different types of lymphatic vessels. Differentiation, 57(2), 97-117.

Schneeberger, E. E., \& Lynch, R. D. (2004). The tight junction: a multifunctional complex. American Journal of Physiology-Cell Physiology, 286(6), C1213-C1228. https:/ / doi.org/10.1152/ajpcell.00558.2003

Schuyler, S. C., \& Pellman, D. (2001). Microtubule "plus-end-tracking proteins": The end is just the beginning. Cell, 105(4), 421-424. https:/ / doi.org/10.1016/s00928674(01)00364-6

Severs, N. J., Rothery, S., Dupont, E., Coppen, S. R., Yeh, H. I., Ko, Y. S., . . Halliday, D. (2001). Immunocytochemical analysis of connexin expression in the healthy and diseased cardiovascular system. Microscopy Research and Technique, 52(3), 301-322. https:/ / doi.org/10.1002/1097-0029(20010201)52:3<301::aid-jemt1015>3.0.co;2-q

Shasby, D. M., Ries, D. R., Shasby, S. S., \& Winter, M. C. (2002). Histamine stimulates phosphorylation of adherens junction proteins and alters their link to vimentin. Am J Physiol Lung Cell Mol Physiol, 282(6), L1330-1338. https:/ / doi.org/10.1152/ajplung.00329.2001

Shaw, R. M., Fay, A. J., Puthenveedu, M. A., von Zastrow, M., Jan, Y. N., \& Jan, L. Y. (2007). Microtubule plus-end-tracking proteins target gap junctions directly from the cell interior to adherens junctions. Cell, 128(3), 547-560. https:/ / doi.org/10.1016/j.cell.2006.12.037

Shaw, S. K., Bamba, P. S., Perkins, B. N., \& Luscinskas, F. W. (2001). Real-time imaging of vascular endothelial-cadherin during leukocyte transmigration across endothelium. Journal of Immunology, 167(4), 2323-2330. https:/ / doi.org/10.4049/jimmunol.167.4.2323

Simionescu, M., \& Simionescu, N. (1991). ENDOTHELIAL TRANSPORT OF MACROMOLECULES - TRANSCYTOSIS AND ENDOCYTOSIS - A LOOK FROM CELL BIOLOGY. Cell Biology Reviews, 25(1), 5-80.

Simionescu, M., Simionescu, N., \& Palade, G. E. (1975). Segmental differentiations of cell junctions in the vascular endothelium. The microvasculature. J Cell Biol, 67(3), 863885. https://doi.org/10.1083/jcb.67.3.863

Simon, A. M., \& Goodenough, D. A. (1998). Diverse functions of vertebrate gap junctions. Trends in Cell Biology, 8(12), 477-483. https://doi.org/10.1016/s0962-8924(98)01372-5

Sollerbrant, K., Raschperger, E., Mirza, M., Engstrom, U., Philipson, L., Ljungdahl, P. O., \& Pettersson, R. F. (2003). The Coxsackievirus and adenovirus receptor (CAR) forms a complex with the PDZ domain-containing protein ligand-of-numb protein-X (LNX). J Biol Chem, 278(9), 7439-7444. https:/ / doi.org/10.1074/jbc.M205927200

Steinberg, M. S., \& McNutt, P. M. (1999). Cadherins and their connections: adhesion junctions have broader functions. Current Opinion in Cell Biology, 11(5), 554-560. https:/ / doi.org/10.1016/s0955-0674(99)00027-7 
Stoletov, K., Strnadel, J., Zardouzian, E., Momiyama, M., Park, F. D., Kelber, J. A., . . . Klemke, R. L. (2013). Role of connexins in metastatic breast cancer and melanoma brain colonization. Journal of Cell Science, 126(4), 904-913. https:/ / doi.org/10.1242/jcs.112748

Stossel, T. P., Chaponnier, C., Ezzell, R. M., Hartwig, J. H., Janmey, P. A., Kwiatkowski, D. J., ... Zaner, K. S. (1985). NONMUSCLE ACTIN-BINDING PROTEINS. Annual Review of Cell Biology, 1, 353-402. https://doi.org/10.1146/annurev.cb.01.110185.002033

Surapisitchat, J., \& Beavo, J. A. (2011). Regulation of Endothelial Barrier Function by Cyclic Nucleotides: The Role of Phosphodiesterases. Phosphodiesterases as Drug Targets, 204, 193-210. https://doi.org/10.1007/978-3-642-17969-3_8

Takahashi, K., Nakanishi, H., Miyahara, M., Mandai, K., Satoh, K., Satoh, A., . . Takai, Y. (1999). Nectin/PRR: An immunoglobulin-like cell adhesion molecule recruited to cadherin-based adherens junctions through interaction with afadin, a PDZ domaincontaining protein. Journal of Cell Biology, 145(3), 539-549. https:/ / doi.org/10.1083/jcb.145.3.539

Takai, Y., Irie, K., Shimizu, K., Sakisaka, T., \& Ikeda, W. (2003). Nectins and nectin-like molecules: Roles in cell adhesion, migration, and polarization. Cancer Science, 94(8), 655-667. https:/ / doi.org/10.1111/j.1349-7006.2003.tb01499.x

Takeichi, M. (1990). CADHERINS - A MOLECULAR FAMILY IMPORTANT IN SELECTIVE CELL-CELL ADHESION. Annual Review of Biochemistry, 59, 237-252. https:/ / doi.org/10.1146/annurev.biochem.59.1.237

Takeichi, M. (1995). Morphogenetic roles of classic cadherins. Curr Opin Cell Biol, 7(5), 619627.

Tinsley, J. H., Wu, M. H., Ma, W. Y., Taulman, A. C., \& Yuan, S. Y. (1999). Activated neutrophils induce hyperpermeability and phosphorylation of adherens junction proteins in coronary venular endothelial cells. Journal of Biological Chemistry, 274(35), 24930-24934. https:// doi.org/10.1074/jbc.274.35.24930

Tsukita, S., \& Furuse, M. (1999). Occludin and claudins in tight-junction strands: leading or supporting players? Trends in Cell Biology, 9(7), 268-273. https:/ / doi.org/10.1016/s0962-8924(99)01578-0

Tsukita, S., Furuse, M., \& Itoh, M. (2001). Multifunctional strands in tight junctions. Nature Reviews Molecular Cell Biology, 2(4), 285-293. https:// doi.org/10.1038/35067088

Tsukita, S., Tanaka, H., \& Tamura, A. (2019). The Claudins: From Tight Junctions to Biological Systems. Trends in Biochemical Sciences, 44(2), 141-152. https:/ / doi.org/10.1016/j.tibs.2018.09.008

Valiron, O., Chevrier, V., Usson, Y., Breviario, F., Job, D., \& Dejana, E. (1996). Desmoplakin expression and organization at human umbilical vein endothelial cell-to-cell junctions. J Cell Sci, 109 ( Pt 8), 2141-2149.

van Horck, F. P. G., Ahmadian, M. R., Haeusler, L. C., Moolenaar, W. H., \& Kranenburg, O. (2001). Characterization of p190RhoGEF, a RhoA-specific guanine nucleotide exchange factor that interacts with microtubules. Journal of Biological Chemistry, 276(7), 4948-4956. https:// doi.org/10.1074/jbc.M003839200

Van Itallie, C. M., \& Anderson, J. M. (2014). Architecture of tight junctions and principles of molecular composition. Seminars in Cell \& Developmental Biology, 36, 157-165. https:/ / doi.org/10.1016/j.semcdb.2014.08.011

vanRijen, H. V. M., vanKempen, M. J. A., Analbers, L. J. S., Rook, M. B., vanGinneken, A. C. G., Gros, D., \& Jongsma, H. J. (1997). Gap junctions in human umbilical cord endothelial cells contain multiple connexins. American Journal of Physiology-Cell Physiology, 272(1), C117-C130.

Verin, A. D., Birukova, A., Wang, P. Y., Liu, F., Becker, P., Birukov, K., \& Garcia, J. G. N. (2001). Microtubule disassembly increases endothelial cell barrier dysfunction: role of 
MLC phosphorylation. American Journal of Physiology-Lung Cellular and Molecular Physiology, 281(3), L565-L574.

Vestweber, D. (2008). VE-cadherin - The major endothelial adhesion molecule controlling cellular junctions and blood vessel formation. Arteriosclerosis Thrombosis and Vascular Biology, 28(2), 223-232. https:/ / doi.org/10.1161/atvbaha.107.158014

Vestweber, D. (2012). Relevance of endothelial junctions in leukocyte extravasation and vascular permeability. Barriers and Channels Formed by Tight Junction Proteins I, 1257, 184-192. https://doi.org/10.1111/j.1749-6632.2012.06558.x

Vestweber, D. (2015). How leukocytes cross the vascular endothelium. Nature Reviews Immunology, 15(11), 692-704. https:/ / doi.org/10.1038/nri3908

Vestweber, D., Wessel, F., \& Nottebaum, A. F. (2014). Similarities and differences in the regulation of leukocyte extravasation and vascular permeability. Seminars in Immunopathology, 36(2), 177-192. https:// doi.org/10.1007/s00281-014-0419-7

Vincent, P. A., Xiao, K. Y., Buckley, K. M., \& Kowalczyk, A. P. (2004). VE-cadherin: adhesion at arm's length. American Journal of Physiology-Cell Physiology, 286(5), C987-C997. https://doi.org/10.1152/ajpcell.00522.2003

Volk, T., \& Geiger, B. (1984). A 135-KD-MEMBRANE PROTEIN OF INTERCELLULAR ADHERENS JUNCTIONS. Embo Journal, 3(10), 2249-2260. https:/ / doi.org/10.1002/j.1460-2075.1984.tb02123.x

Volk, T., \& Geiger, B. (1986). A-CAM - A 135-KD RECEPTOR OF INTERCELLULAR ADHERENS JUNCTIONS .1. IMMUNOELECTRON MICROSCOPIC LOCALIZATION AND BIOCHEMICAL-STUDIES. Journal of Cell Biology, 103(4), 1441-1450. https://doi.org/10.1083/jcb.103.4.1441

Voura, E. B., Sandig, M., \& Siu, C. H. (1998). Cell-cell interactions during transendothelial migration of tumor cells. Microscopy Research and Technique, 43(3), 265-275. https:/ / doi.org/10.1002/(sici)1097-0029(19981101)43:3<265::aid-jemt9>3.0.co;2-z

Wade, R. H., \& Hyman, A. A. (1997). Microtubule structure and dynamics. Curr Opin Cell Biol, 9(1), 12-17.

Wainwright, M. S., Rossi, J., Schavocky, J., Crawford, S., Steinhorn, D., Velentza, A. V., . . Watterson, D. M. (2003). Protein kinase involved in lung injury susceptibility: Evidence from enzyme isoform genetic knockout and in vivo inhibitor treatment. Proceedings of the National Academy of Sciences of the United States of America, 100(10), 6233-6238. https://doi.org/10.1073/pnas.1031595100

Wallez, Y., \& Huber, P. (2008). Endothelial adherens and tight junctions in vascular homeostasis, inflammation and angiogenesis. Biochimica Et Biophysica ActaBiomembranes, 1778(3), 794-809. https:// doi.org/10.1016/j.bbamem.2007.09.003

Watanabe, T., Wang, S. J., Noritake, J., Sato, K., Fukata, M., Takefuji, M., . . Kaibuchi, K. (2004). Interaction with IQGAP1 links APC to Rac1, Cdc42, and actin filaments during cell polarization and migration. Developmental Cell, 7(6), 871-883. https:/ / doi.org/10.1016/j.devcel.2004.10.017

WatermanStorer, C. M., \& Salmon, E. D. (1997). Microtubule dynamics: Treadmilling comes around again. Current Biology, 7(6), R369-R372. https:/ / doi.org/10.1016/s09609822(06)00177-1

Williams, L. A., Martin-Padura, I., Dejana, E., Hogg, N., \& Simmons, D. L. (1999). Identification and characterisation of human Junctional Adhesion Molecule (JAM). Molecular Immunology, 36(17), 1175-1188. https:/ / doi.org/10.1016/s01615890(99)00122-4

Witt, K. A., Mark, K. S., Hom, S., \& Davis, T. P. (2003). Effects of hypoxia-reoxygenation on rat blood-brain barrier permeability and tight junctional protein expression. American Journal of Physiology-Heart and Circulatory Physiology, 285(6), H2820-H2831. https://doi.org/10.1152/ajpheart.00589.2003 
Wolburg, H., \& Lippoldt, A. (2002). Tight junctions of the blood-brain barrier: Development, composition and regulation. Vascular Pharmacology, 38(6), 323-337, Article Pii s15371891(02)00200-8. https://doi.org/10.1016/s1537-1891(02)00200-8

Yagi, T., \& Takeichi, M. (2000). Cadherin superfamily genes: functions, genomic organization, and neurologic diversity. Genes $\mathcal{E}$ Development, 14(10), 1169-1180.

Yanagisawa, M., Kaverina, I. N., Wang, A. X., Fujita, Y., Reynolds, A. B., \& Anastasiadis, P. Z. (2004). A novel interaction between kinesin and p120 modulates p120 localization and function. Journal of Biological Chemistry, 279(10), 9512-9521. https:/ / doi.org/10.1074/jbc.M310895200

Yeager, M., \& Nicholson, B. J. (1996). Structure of gap junction intercellular channels. Current Opinion in Structural Biology, 6(2), 183-192. https://doi.org/10.1016/s0959440x(96)80073-x

Yeh, H. I., Rothery, S., Dupont, E., Coppen, S. R., \& Severs, N. J. (1998). Individual gap junction plaques contain multiple connexins in arterial endothelium. Circulation Research, 83(12), 1248-1263. https:// doi.org/10.1161/01.res.83.12.1248

Zhang, X. H., Sun, Y., Wang, Z. Y., Huang, Z. P., Li, B. Z., \& Fu, J. X. (2015). Up-regulation of connexin-43 expression in bone marrow mesenchymal stem cells plays a crucial role in adhesion and migration of multiple myeloma cells. Leukemia \& Lymphoma, 56(1), 211-218. https:// doi.org/10.3109/10428194.2014.913289

Zhurinsky, J., Shtutman, M., \& Ben-Ze'ev, A. (2000). Plakoglobin and beta-catenin: protein interactions, regulation and biological roles. Journal of Cell Science, 113(18), 3127-3139. 